\title{
Yoga in School Education
}

\author{
Kalpana Venugopal* \\ Professor of Education, Regional Institute of Education (NCERT), India
}

Submission: August 21, 2017; Published: August 24, 2017

*Corresponding author: Kalpana Venugopal, Professor of Education, Regional Institute of Education (NCERT), Mysore, India, Email: kalpanavp@rediffmail.com

\section{Introduction}

Yoga makes a note worthy difference in the sense of well being of children of all ages and from all backgrounds. Regular practice of yogic postures enhances the ability of students to concentrate, to deal with impulsive behaviour, and to think more clearly. It helps mental equilibrium and self-control. Yoga teaches children to be gentle with themselves and others. It generates positive emotions and compassion. Furthermore, yoga reduces stress and helps children to release tension and relax. It helps children develop lifelong health habits (both physical and mental), i.e. acquaints them with the option of healthy practice of exercises for the body and brain [1]. Yoga offers students a balanced and safe way for them to relate with themselves and to their surroundings, both through inner \& outer awareness. Practising yoga intensifies self-confidence as the students measure their own individual success and improvement. Yoga promotes group cooperation \&accelerates the learning of vocabulary in a playful manner [2]. It has an exhilarating and calming effect, which in later life could lead to a marked reduction of stress, blood pressure problems postural and nervous disorders. Children enjoy associating the name of a pose with the characteristics of the animals and other aspects of nature it represents, thus relating to the oneness of creation [3]. Recognising all these benefits, which are based on sound research and practice most countries have recommended for yoga in school education.

A distinctive aspect of Yoga is the attention and mental focus that children learn to exercise while doing the postures. The result is the toning up of both the body and mind. In adopting and maintaining a posture there is a certain co-ordination between the muscular system and the nervous system, that influences the physical and mental behaviours. Yogic postures do not just invigorate the body but also aid immensely to keep the mind healthy and calm thus bringing a feeling of refreshment. The physical benefits are improvement of flexibility, freedom of movement, better posture \& gait, improved digestion, circulation, nervous, \& endocrine systems and stronger resistance, coordination of body and mind through postures
[4]. Improved concentration, self-control; self confidence; focus upon one thing at a time, awareness of themselves, their abilities \& individual differences; persistence \& perseverance to attain; observation \& self assessment; appreciation of silence; seeking for perfection, are all learned through control of breath and body postures [1]. This has great implication for academic learning [5]. The mental benefits of yoga are immense such as relaxation, calmness of mind, increased concentration, appreciation of silence, self-control, better coping with stress \& tension, and generates positive emotions. It also harnesses mental energy \& effort, helps deal with impulsive behaviour and enables to think more clearly [2]. Yogic practices can remove the psychological blocks in the minds of children and also make them aware of the psychological changes that happen in their body and brain. It can make them aware of their own distractions and give them the ability to focus on the theme of the subject they are studying. It can improve their responses, creativity, receptivity, memory, willpower and behavior [6]. Awareness and consciousness of body and mind makes them to be aware of their own abilities. Alertness and mindfulness makes them to be aware of meaningful learning and to seek meaning in learning. Visualization in meditation aids in stimulating the senses and promotes creativity [3]. Children will be more relaxed, focused, one-pointed and tranquil and less destructive, restless, violent and distracted, in class. All this accelerates learning and improves performance in school. It costs virtually nothing to set up a time for yoga lessons. A 10-minute yoga session per day is adequate and it does not require any equipment. Any open classroom is sufficient for conducting a yoga class. Yoga is not a religious practice, nor does it conflict with any religion, it is a way of life. The sooner it is learned and practiced in life the quality of life is assured. Therefore it is imperative to begin this early in life and school is the best agency to do so.

In India, Yoga has been an integral part of Health and Physical Education that has been a compulsory subject up to the secondary school stage, since 1988. The National Curriculum Framework 2005 [5] adopted a holistic definition of health in 
which yoga is an integral part of it. Yoga has been introduced from Class VI onwards, though yogic activities may begin in an informal way from primary classes onwards. The success of this effort depends on the steps that school principals and teachers take to encourage children to practice Yoga and reflect on their learning. It has been observed that yoga and physical education have not been given the due importance in school education and neither has their contribution to the health and overall development of the child been adequately acknowledged [7]. The constraints faced by yoga and physical education is related to a number of factors that affect the quality of school education in general and health and physical education in particular. In order to make this subject on par with other subjects of school education, it is important in advocating it as having a strong experiential learning component and not just instructive [5]. Therefore, emphasis should be on preparing and training teachers in yoga by focusing on the comprehensiveness of the area of health and physical education.

The experience of initiating yoga in school curriculum has been a mixed experience. There is a tendency of reducing yoga to a mere physical exercise, which defeats the very essence of this practice. Presently there is shortage of trained yoga teachers, which is related to the non-availability of adequate number of institutions that have the capacity and expertise for this purpose. The role of the National Council for Teacher Education in this regard is laudable [8]. The modules prepared by the NCTE on Yoga Education for the Diploma, Bachelor and Masters programs in Education are intended to fulfill the great expectations that the society has placed on teachers and teacher educators in respect of development of composite personality in teacher educators and teachers, and in turn in the students. It is indeed gratifying that Yoga Education has been made a compulsory paper/area of study for more than 18,000 teacher education institutions teaching above 14 lakh teachers through above 3 lakh teacher educators/ faculty members. This is historic for India, for this is the first time that Yoga Education has been made compulsory nationally for all the teacher educators and student teachers in the country. [7] Yoga is the single most area of learning, which is capable for effecting the holistic development of the human personality. Yoga has its roots in Indian traditions and culture, and it is scientific in method, content and verifiable like any other academic discipline. In view of the above, the NCTE developed learning materials, which is authentic and secular, and free from any sectarian biases [8]. The materials developed satisfy the criteria of secularism and democracy and, in most cases, possess research-based authenticity.

Yoga aims at the total development of the human personality, impacting upon its different dimensions and facets-the individual and social; emotional and cognitive, psychomotor and behavioral, and eventually moral and spiritual [6]. If regularly and properly practiced, Yoga has the potential to transform an individual into a vibrant personality, full of energy and enthusiasm. It can give poise and tranquility, a sharp memory, concentration, a creative mind, resistance against diseases and holistic health [3]. All of these needs to be worked upon from childhood for fuller benefits and therefore it should be a part of school life. Second, it is a truism that for spreading the message of Yoga and making it a mass movement no other agency, except that of the school and the teachers can be most effective; therefore, inclusion of Yoga education in school and teacher education cannot be over emphasized.

\section{References}

1. Butzer B, Lo Russo AM, Windsor R, Riley F, Frame K, et al. (2017) A Qualitative examination of yoga for middle school Adolescents. Advances in School Mental Health Promotion 10(3): 195-219.

2. Govindarajulu N, Gannadeepam J, Bera TK (2015) Effect of yoga practices on flexibility and cardio-respiratory endurance of high school girls. Yoga Mimamsa 84(2): 64-70.

3. Ganguly SK, Bera TK, Gharote ML (2013) Yoga in relation to health related physical fitness and academic achievement of school boys. Yoga Mimamsa 94(3-4): 118-123.

4. Conboy LA, Noggle JJ, Frey JL, Kudesia RS, Khalsa SB (2013) Qualitative evaluation of a high school yoga program: feasibility and perceived benefits. Explore (NY) 9(3): 171-180.

5. NCERT (2005) National Curriculum Framework, NCERT, New Delhi, India.

6. Wang D, Hagins M (2016) Perceived Benefits of Yoga among Urban School Students: A Qualitative Analysis. Evidence-Based Complementary and Alternative Medicine 2016(2016): 7.

7. GOI (2015) Report of the School Health Committee-Part I, Govt. of India, Ministry of Health, New Delhi, India.

8. NCTE (2015) Yoga Education. National Council for Teacher Education, New Delhi, India.

\section{Your next submission with Juniper Publishers} will reach you the below assets

- Quality Editorial service

- Swift Peer Review

- Reprints availability

- E-prints Service

- Manuscript Podcast for convenient understanding

- Global attainment for your research

- Manuscript accessibility in different formats ( Pdf, E-pub, Full Text, Audio)

- Unceasing customer service

Track the below URL for one-step submission https://juniperpublishers.com/online-submission.php 